\title{
FACILITATING THE HOUSING BARGAINING WITH THE HELP OF THE BARGAINING DECISION SUPPORT SYSTEM
}

\author{
Vita URBANAVIČIENĖ a,*, Artūras KAKLAUSKAS a, Edmundas Kazimieras ZAVADSKAS b, \\ Jūratė S̆LIOGERIENĖ a, Jurga NAIMAVIČIENĖ a, Nikolay Ivanovich VATIN c \\ ${ }^{a}$ Department of Construction Economics and Property Management, Vilnius Gediminas Technical Uni- \\ versity, Sauletekio al. 11, LT-10223 Vilnius, Lithuania \\ ${ }^{b}$ Department of Construction Technology and Management, Vilnius Gediminas Technical University, \\ Sauletekio al. 11, LT-10223 Vilnius, Lithuania \\ ${ }^{c}$ Civil Engineering Institute of Saint-Petersburg State Polytechnical University, Polytehnicheskaya 29, \\ 195251 Saint Petersburg, Russia
}

Received 10 December 2013; accepted 14 May 2014

\begin{abstract}
More than 90 percent home buyers today rely on the Internet as one of their primary research sources and real estate related searches continually grows. Internet helps buyers to find and select bigger number of right homes for sale in a shorter time, so provides more alternatives for bargaining. The bargaining is an inseparable part of the home buying and selling process. However, housing bargaining mostly is conducted face-to face, so there is a growing need for facilitating the housing bargaining and conducting such bargaining on the Web with the help of the systems. The article describes the developed Real-Time Housing Multiple Criteria Bargaining Decision Support System, based on multiple-criteria mathematical methods, which helps to improve the efficiency of bargaining through the following functions: search for housing alternatives; formulation of the initial comparative table of alternatives; multiple criteria analysis of housing alternatives and negotiation tactics; determination of the most useful home option for buying; presentation of recommendations and real-time determination of a home's market value; e-bargaining using templates of bargaining e-mails generated by the system.
\end{abstract}

KEYWORDS: Housing; Real estate; Bargaining; Negotiations; Decision-making; Decision support system; Multiple criteria analysis

\section{INTRODUCTION}

In a rapidly changing real estate market conditions and the large demand and supply for real estate, it is difficult to adequately orient all the above in the existing situation and to make rational decisions and property bargaining without the help of the decision support systems, knowledge and databases.

Over the past decade the world of real estate (RE) buyers has become increasingly digital. More than 90 percent home buyers today rely on the Internet as one of their primary research sources and RE related searches on Google.com continually noticeably grew year-over year, especially grew $\mathrm{RE}$ searches on mobile devices -120 percent from 2011 to 2012 (NAR 2012). Internet helps buyers to find and select bigger number of right homes for

\footnotetext{
* Corresponding author. E-mail: vita.urbanaviciene@vgtu.lt
}

sale in a shorter time, so provides more alternatives for bargaining. Bargaining (as a type of negotiation) means decision-making.

The real estate prices depend not only on the supply-demand ratio in the market, the competitive developers prices and the reasons of real estate buying or selling, but also, to a large extent, on the negotiation skills of buyers and sellers (McKenzie, Betts 2006; Gruneberg, Ive 2000). Based on his personal experience at work, Cummins (1999) writes that about $95 \%$ of buyers overpay for real estate due to the lack of knowledge and experience at negotiations and pay more than expected by the seller.

Negotiation outcome and utility depend on negotiation context (for example, negotiation motives, criteria used by negotiation parties, presence of third party), negotiator characteristics (such as personality types, whom the negotiators represent), 
selected strategy and tactics (Urbanavičienè et al. 2009). For example, Barry and Friedman (1998) think that individual characteristics of negotiators are very significant in negotiations. Raiffa (1982) claimed that thorough assessment of the other negotiating party is more important than an assumption that it acts only on a rational basis. Bazerman et al. (2000) believe that the perception, beliefs and mental models (interpretation of occurring situations) and internal motives, such as emotions (mental state of the decision-maker) and attitudes (the relation between the psychological tendency of a decision-maker to have a certain perception of his/ her personality and the specific phenomenon in his/her environment) may influence decisions in negotiations. Besides, the memory of former decisions and their outcomes is a critical cognitive function, which also makes huge impact on the direct decision-making (The Nobel Foundation 2002). For example, Diekmann et al. (1996) studies shows, both RE sellers and buyers, are affected by the amount sellers previously paid for their property and affect the bargaining decisions and outcome: (1) buyers base their initial and highest offers on the sellers' previous purchase price; (2) sellers base their lowest acceptable offers on their previous purchase price; (3) the sellers' previous purchase price affects not only the buyers' and sellers' offers and expectations, but also the final negotiated outcome. Just like bargaining, the home buying and selling process also always means decision-making. Consumer research has demonstrated that emotions play an important role in decision-making (Garg et al. 2007). Research also suggests that feelings play an important role in the formation of attitudes and judgements about advertisements and can be an important mediator in explaining the relationship between cognitive and behavioural reactions to advertising stimuli (Kemp et al. 2012).

During housing searching, buying and bargaining processes home buyers and sellers experience a lot of emotions and stressfully situations, which may influence their decisions considerably. For example, in some cases seller's emotional state is direct reason of $\mathrm{RE}$ sales prices falling considerably below the average market price (McLean, Eldred 2005). Despite Internet helps buyers to find and select bigger number of right homes for sale in a shorter time, finding the right home is the most difficult step in the home buying process (NAR 2013). Flavián-Blanco et al. (2011) investigated the emotional outcomes of the online search process. The results of their study show that the emotional out- comes of an online search process can be influenced by different structures of perceptions, affective states and emotions felt during the search activity.

The bargaining is an inseparable part of the home buying and selling process. Email has profoundly influenced the way people communicate personally and professionally and, for many, email negotiations have become a common, every day experience (Geiger, Parlamis 2014). However, housing bargaining mostly is conducted face-to face, so there is a growing need for facilitating the housing bargaining and conducting such bargaining on the Web with the help of the systems. Also bargaining means communication between negotiating parties. Advanced technologies used in negotiations help to make the decisions. The scientific literature describes various types of negotiation decision support systems (NDSS) (Rangaswamy, Shell 1997; Chiu et al. 2005; Agrawal, Chari 2009; Kersten, Lai 2010). NDSS are often classified according to the level of (analytical) support to negotiators (Vetschera 2007).

The software and systems described in scientific literature and designed to assist negotiators and to automate negotiations include: decision support systems (DSS), group decision support systems (GDSS), negotiation decision support systems (NDSS), meeting support systems (MSS), negotiation software agents and negotiation software agents-assistants. All of them now are commonly classified as electronic negotiation systems (ENS) (Kim et al. 2007; Kersten, Lai 2010).

Schoop describes three main classes of negotiation support: (1) the automation oriented approaches aiming at automating the negotiation process in order to find an economic optimum, (2) the communication-oriented approaches supporting the communicative processes involved in any negotiations, (3) the document-oriented approaches enabling document exchange and management (Schoop 2004). Efficient housing bargaining system must have all the three above mentioned classes of support.

Notwithstanding the potential promises of ENShosted negotiations, their real-life usage has been limited (Carbonneau, Vahidov 2014). Catalogues and auctions remain the pre-dominant forms of mechanism in the online applications. There are only a few different NDSS suitable for property bargaining, namely MEDIATOR (Li 1996), virtual real estate agent (Yen et al. 2000), WebNS (Yuan et al. 2003), Negoisst (Schoop et al. 2003), electronic negotiation of government contracts (Paliwal et al. 2003), e-negotiations through mutual 
services (Cheung et al. 2003). Recent study done by Pommeranz et al. (2012) investigated the possibility of use of negotiation support system in mobile devices. The data showed that in real estate negotiations people would use such system mostly for data gathering and preparing for negotiations, not for conducting real bargaining.

Today RE portals offer information on homes for sale and facilitate a very detailed search online. Some offer buyers and sellers a possibility to communicate by e-mail in order to offer a price or to get information about price changes, but the housing bargaining process is not supported. People still negotiate real estate contracts face-to-face and usually assisted by an RE agent. Though RE portals do allow finding thousands of homes for sale, they do not help buyers evaluate housing alternatives and offer no information on market prices and recent sales.

To bargain successfully, it is vital to have information on the actual market value of properties. Moreover, a 2011 multiple criteria assessment of engineered infrastructure revealed that properties should be valuated taking a wider scope, rather than technical or economic attributes alone (Šliogeriene et al. 2012). The property market is always in the eye of the public, as it serves the primary needs; thus property valuation should also consider additional factors, i.e. socio-cultural ones.

In view of the diverse facets of property bargaining discussed above, the authors have created The Real-Time Housing Multiple Criteria Bargaining Decision Support System. The developed System was based on the research and findings of scientists (taken from the literature review) on real estate negotiation research (Gibler, Nelson 2003; Yavas 2007), negotiation support systems (Kersten, Lai 2010; Druckman et al. 2012), e-negotiation versus face-to-face negotiation (Galin et al. 2007), communication and effects of multimedia communication in web-based negotiation (Yuan et al. 2003; Valley et al. 2002, van der Amselvoort et al. 2011), information and communication technology in the RE industry (Kummerow, Lun 2005), impact of and interaction between behavioral and economic decision support in electronic negotiations (Gettinger et al. 2012) as well as on the previous created the conceptual model of construction and real estate negotiation (Urbanavičienè $e t a l$. 2009). As e-mail negotiations in RE become more common (RENI 2014), the authors believe it is important to implement e-bargaining letters (based on negotiation tactics) in to the system - to ensure the best possible outcome in housing bargaining.
The paper is structured as follows. Following this introduction, Sect. 2 describes the developed Real-Time Housing Multiple Criteria Bargaining Decision Support System. In Sect. 3 is presented work with the developed system and samples of prepared e-bargaining letters. Sect. 4 provides with the system testing results and an example of practical implementation using multiple criteria methods in decision-making of the housing bargaining using the RTMC-BDSS. Finally, some concluding remarks are provided in Sect. 5 .

\section{THE REAL-TIME HOUSING MULTIPLE-CRITERIA BARGAINING DECISION SUPPORT SYSTEM}

The scientists of Vilnius Gediminas Technical University created The Real-Time Housing Multiple-Criteria Bargaining Decision Support System (RTMC-BDSS). The previous developed conceptual model of construction and real estate negotiation and the algorithm of the conducted home sales negotiation were integrated into the created The Real-Time Housing Multiple-Criteria Bargaining Decision Support System. The DSS is based on the multiple criteria analysis methods developed by Kaklauskas and Zavadskas (1996a, 1996b), that allow an integrated assessment of technical, economic, sustainability and social aspects. The templates of e-bargaining letters were prepared by the authors based on the more common negotiation tactics used in housing bargaining.

The created Real-Time Housing Multiple-Criteria Bargaining Decision Support System consists of a database, a database management system, module-base, a module-base management system and a user interface (Fig. 1).

Values of quantitative and qualitative criteria (Table 1) have been selected after analysis of relevant literature and created model. Significance of criteria has been determined through expert evaluation method.

The RTMC-BDSS enables processing of large amounts of data and monitoring of changes of all criteria in question. A significant advantage is that the RTMC-BDSS determines the real-time market value of the flats, displays the intermediate results, which reflect the impact of each criterion on the utility and value.

The system automatically solves the multiple criteria problem and presents the results. During bargaining the buyer and the seller with the help of RTMC-BDSS may perform real calculations (the utility degree, market value and purchase 
The Real-Time Housing Multiple-Criteria Bargaining Decision Support System (RTMC-BDSS)

\begin{tabular}{|c|c|}
\hline \multicolumn{2}{|c|}{ User interface } \\
\hline$\downarrow$ & $\downarrow$ \\
\hline Database management system & Module-base management system \\
\hline $\begin{array}{l}\text { - Database of housing } \\
\text { - Initial bargaining tables } \\
\text { - Database of standard bargaining e- } \\
\text { letters } \\
\text { - Tables of assessment of the priority } \\
\text { and utility of the bargaining deci- } \\
\text { sions } \\
\text { - Database of criteria and weight of } \\
\text { criteria }\end{array}$ & $\begin{array}{l}\text { - A searching model for housing alternatives } \\
\text { - A model for finding alternatives and making an } \\
\text { initial bargaining table } \\
\text { - A model of multiple criteria analysis of housing, } \\
\text { negotiation tactics or other alternatives } \\
\text { - A model for bargaining based on real calculations } \\
\text { - A model for determining the most rational home } \\
\text { purchase variant } \\
\text { - A provision model of recommendations and real- } \\
\text { time determination of a home's market value } \\
\text { - A model for determining the rational negotiation } \\
\text { tactics } \\
\text { - A model of e-bargaining letters }\end{array}$ \\
\hline
\end{tabular}

Fig. 1. The components of the Real-Time Housing Multiple-Criteria Bargaining Decision Support System

Table 1. Criteria for housing bargaining

\begin{tabular}{llc}
\hline Criterion & Unit & Weig \\
\hline Residential area (location in the city) & Points & 0.09 \\
Supply (asking) price & LTL & 0.098 \\
Floor area & Sq. m & 0.08 \\
Condition of the building & Points & 0.08
\end{tabular}

Distance to a main street:

close, i.e. $<130 \mathrm{~m}$

average distance, i.e. $130-550 \mathrm{~m}$

far, i.e. $>550 \mathrm{~m}$

House type (external walls)

View from windows

Available parking next to the house

Condition of the flat

Balcony or terrace

Window orientation (natural lighting): flats with north-facing windows $(\mathrm{N})$ are the cheapest, flats with south-facing windows (S) are higher on the price scale, and flats with west- and east-facing windows are the most expensive

Site landscaping (whether the yard and the site around the building are properly landscaped with playing grounds, lawns, etc.)

Prestigious areas

(In Vilnius, the prime areas are the Old Town, Užupis, Downtown, Naujamiestis, Žverrynas and Antakalnis; while Naujininkai, Vilkpèdè and Paneriai are the least desirable areas)
Points

0.056

Points

0.054

Points $0.068 \quad$ close -1 ;

average distance -2 ;

far -3 .

Points $\quad 0.057$

masonry (bricks, blocks) - 3; monolithic, other -2 ;

large-panel - 1 .

scenic -3 ; regular -2 ;

bleak (or windows overlooking a main street) -1 .

sufficient -2 ; insufficient -1 .

repaired -3 ; in good condition -2 ; needs repair -1 .

Points $\quad 0.052$ yes -2 ; no -1 .

Points $0.051 \quad$ north-facing $(\mathrm{N})-1$;

south-facing (S) or all windows facing the same direction, also when they face north and other cardinal directions -2 ;

facing the remaining two cardinal directions -3 .

Points $\quad 0.047 \quad$ landscaped - 2; no harmony in the environment -1 .

Points $\quad 0.046 \quad$ prime area -2 ;

non-prime area -1 .

(Continued) 


\begin{tabular}{|c|c|c|c|}
\hline Criterion & Unit & Weight & Values \\
\hline $\begin{array}{l}\text { (Continued) } \\
\text { Distance to a water body, park, green area: } \\
\text { close, i.e. }<350 \mathrm{~m} \\
\text { average distance, i.e. } 350-1350 \mathrm{~m} \\
\text { far, i.e. }>1350 \mathrm{~m}\end{array}$ & Points & 0.038 & $\begin{array}{l}\text { close }-3 \text {; } \\
\text { average distance }-2 \\
\text { far }-1\end{array}$ \\
\hline $\begin{array}{l}\text { Distance to a school or kindergarten: } \\
\text { close, i.e. }<250 \mathrm{~m} \\
\text { average distance, i.e. } 250-850 \mathrm{~m} \\
\text { far, i.e. }>850 \mathrm{~m}\end{array}$ & Points & 0.035 & $\begin{array}{l}\text { close }-3 \\
\text { average distance }-2 \\
\text { far }-1\end{array}$ \\
\hline $\begin{array}{l}\text { Distance to a public transport stop: } \\
\text { close, i.e. }<220 \mathrm{~m} \\
\text { average distance, i.e. } 220-900 \mathrm{~m} \\
\text { far, i.e. }>900 \mathrm{~m}\end{array}$ & Points & 0.034 & $\begin{array}{l}\text { close }-3 \text {; } \\
\text { average distance }-2 \text {; } \\
\text { far }-1\end{array}$ \\
\hline $\begin{array}{l}\text { Distance to a large supermarket: } \\
\text { close, i.e. }<250 \mathrm{~m} \\
\text { average distance, i.e. } 250-850 \mathrm{~m} \\
\text { far, i.e. }>850 \mathrm{~m}\end{array}$ & Points & 0.032 & $\begin{array}{l}\text { close }-3 \\
\text { average distance }-2 \\
\text { far }-1\end{array}$ \\
\hline
\end{tabular}

priorities) of the homes and analyse the effect of each selected criterion on the value of alternatives.

The created Real-Time Housing Multiple-Criteria Bargaining Decision Support System considers each negotiation tactics, generates relevant bargaining e-mails and, once the buyer has reviewed and revised them, sends them to home sellers selected by the buyer for bargaining.

The system may be supplemented with new objects and data about them. The system, with the same weights of the criteria, may also be employed to determine the utility, identify the value, and analyse various pieces of property. It is a universal and easy-to-use system; its set of criteria and their weights may be adjusted to meet any research goals or needs.

The developed RTMC-BDSS helps to improve the efficiency of bargaining through the following functions: search for housing alternatives; formulation of the initial comparative table of alternatives; multiple criteria analysis of housing alternatives; multiple criteria analysis of negotiation tactics; determination of the most useful home option for buying; presentation of recommendations and realtime determination of a home's market value; ebargaining using templates of bargaining e-mails generated by the system. This way the system saves time and helps the user find a suitable home faster, discover its market value, make informed bargaining decisions, and speed up the bargaining. Automated determination of the market value benefits both the buyer and the seller, because it speeds up the conclusion of a deal at a fair price.

The system can be found at the following web address: http://iti.vgtu.lt/imitacijosmain

\section{WORK WITH THE REAL-TIME HOUSING MULTIPLE-CRITERIA BARGAINING DECISION SUPPORT SYSTEM}

Using the system includes the following steps:

1. Registration and Log in.

2. Overview of available homes. The user is taken to a screen which offers to filter the assessment results by the type of housing (e.g. two-rooms flat or other). Once the alternatives are selected, the user will see a table with the results. The user may take a look at all available housing options by clicking the ID next to the alternative of interest (e.g. flat) in the table compiled by the system. The click on the ID opens a window with a brief free-form description of the flat for sale and a picture of the building (Fig. 2).

3. Description of the alternatives. To compare the qualitative and quantitative characteristics of the homes added to the list, the user has to

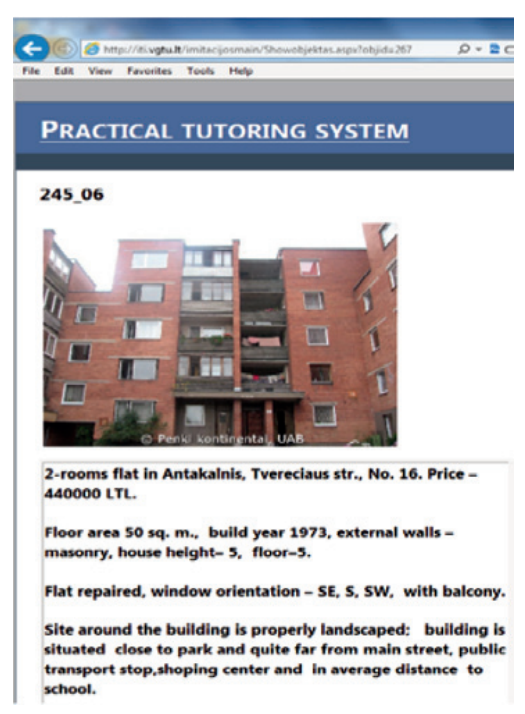

Fig. 2. Description of flats for sale 
click the link Description of the alternatives. A new window opens with the details in a table (Fig. 3).

4. Multiple criteria assessment of the alternatives. To make a more thorough multiple criteria analysis, the user has to click the link Results of multiple criteria evaluation of the alternatives. By clicking this link the user is taken to a screen which offers to filter the assessment results by the type of housing or negotiation tactics. Once the alternatives are selected, the user will see a table with the results of their multiple criteria assessment (Fig. 4). A click on the value of any selected criterion in a matrix cell on the links AVG, MIN displays the value of each selected criterion in percent compared to the same criterion of other objects.

Clicking the link "Results of Multiple Criteria Evaluation" of negotiation tactics, the results of the multiple criteria evaluation of the alternatives are thus demonstrated (see Fig. 5). In conducted home sales bargaining case, the created RTMC-BDSS shows that the tactics "Would you sell for .....LTL?" has the priority and the buyer might use it in order to bargain a better price for housing.

5. Recommendations. The system's recommender model analyses the results, as well as pricedetermining criteria and their values, and then offers recommendations how to improve the object's market value by making individual criteria either more significant or less significant.

The RTMC-BDSS makes it possible to compare a home's asking price with its market price. Using the multiple criteria methods and the available details about flats for sale, the system may figure out the market value of the flats. The RTMC-BDSS considers the prices of comparative objects already sold, and figures out the market value by approximation (Fig. 6).

6. Bargaining. For bargaining purpose, the flats have to be ticked next to their ID in the multiple criteria assessment window. Once all bargaining alternatives (flats) are ticked, the user has to click Make proposal and then Send. The system then emails the multiple criteria analysis results and a proposal to lower the asking price to the bargaining partners. In such e-mails, standard bargaining e-mail templates are used. More common alternatives (negotiation tactics) used in housing bargaining, such as "Go away", "An attractive alternative", "No more money" and others, were selected for housing bargaining templates.

7. Replying to a bargaining proposal. The seller receives two copies of the bargaining proposal, one by e-mail and one to his or her personal proposal box in the system's database.

The proposal box comprises two sections: all incoming bargaining offers are stored in the Inbox, and all outgoing offers are stored in the Outbox. To view a bargaining e-mail stored in the system, the user has to click the proposal box icon. Then the emailed proposal with a brief text and the table of multiple criteria analysis opens. To reject a bargaining proposal, the user has to click the option Reject; to view the terms of the proposal the user has to open the bargaining calculator by clicking Ref. No.

The system is designed to make it possible to look at several variants of a bargaining reply and to pick out the one that promises the most benefit. The bargaining object is displayed in the system first and its characteristics may be modified. If the other bargaining party is believed to have misconstrued the assessment criteria, their weights may also be modified. Once these actions are done, the user has to click the button Calculate to view the reanalysed details. The buyer then receives a reply to his or her bargaining e-mail. Upon logging in to the system the user sees the price proposed by the seller with its decrease indicated by a red arrow.

8. Samples of standard bargaining e-mails generated by the system. Note: The phrases that may be modified in view of the user's situation or wishes are in different colour in the emails.

\section{An attractive alternative tactics}

\section{Hello,}

I'm currently looking for a flat to buy. The flat you offer has caught my eye, as it is almost a perfect match to my wishes. Yet there is another similar flat offered for a price very close to your ask price, but it is of newer construction and I find its layout better.

These factors are not my prime criteria when I consider a flat; my choice depends more on the price. So if you would consider cutting your price by LTL 10,000, I think I might choose your flat and we could sign the sales contract in the nearest future.

I'll be waiting for your reply until Monday, because on that day I've arranged a meeting with the owners of the aforesaid other flat and I would loath to keep them waiting.

Sincerely yours,

Buyer 


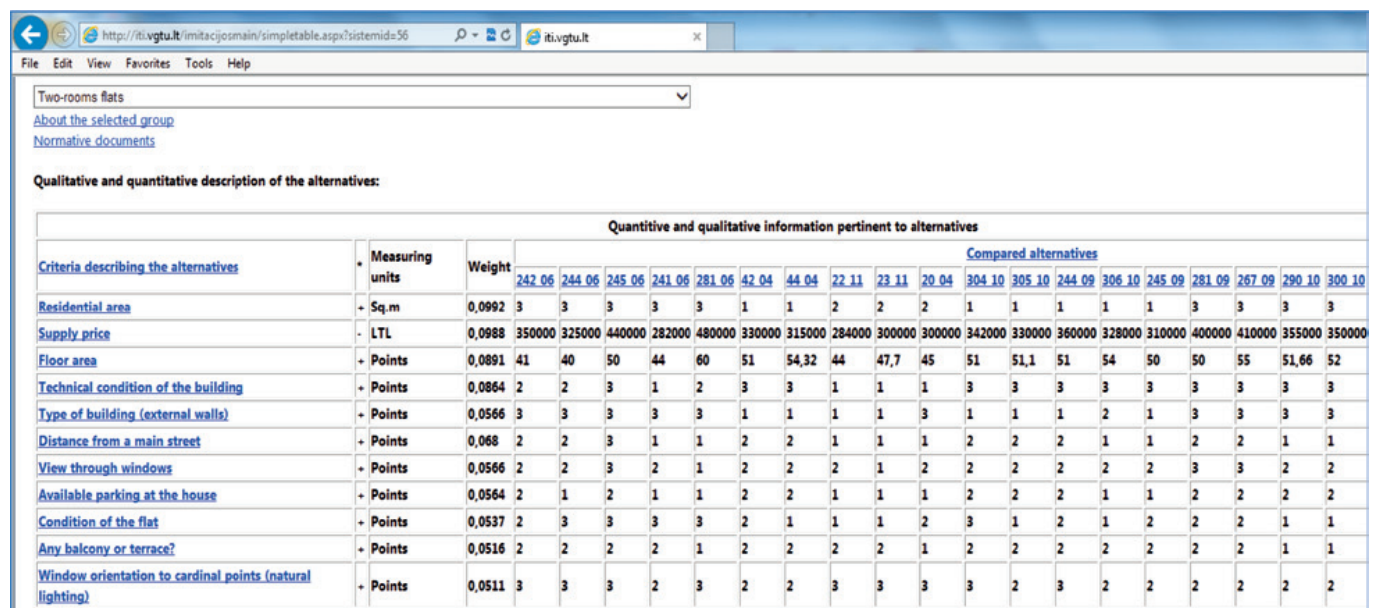

Fig. 3. Quantitative and qualitative description of alternative flats for sale

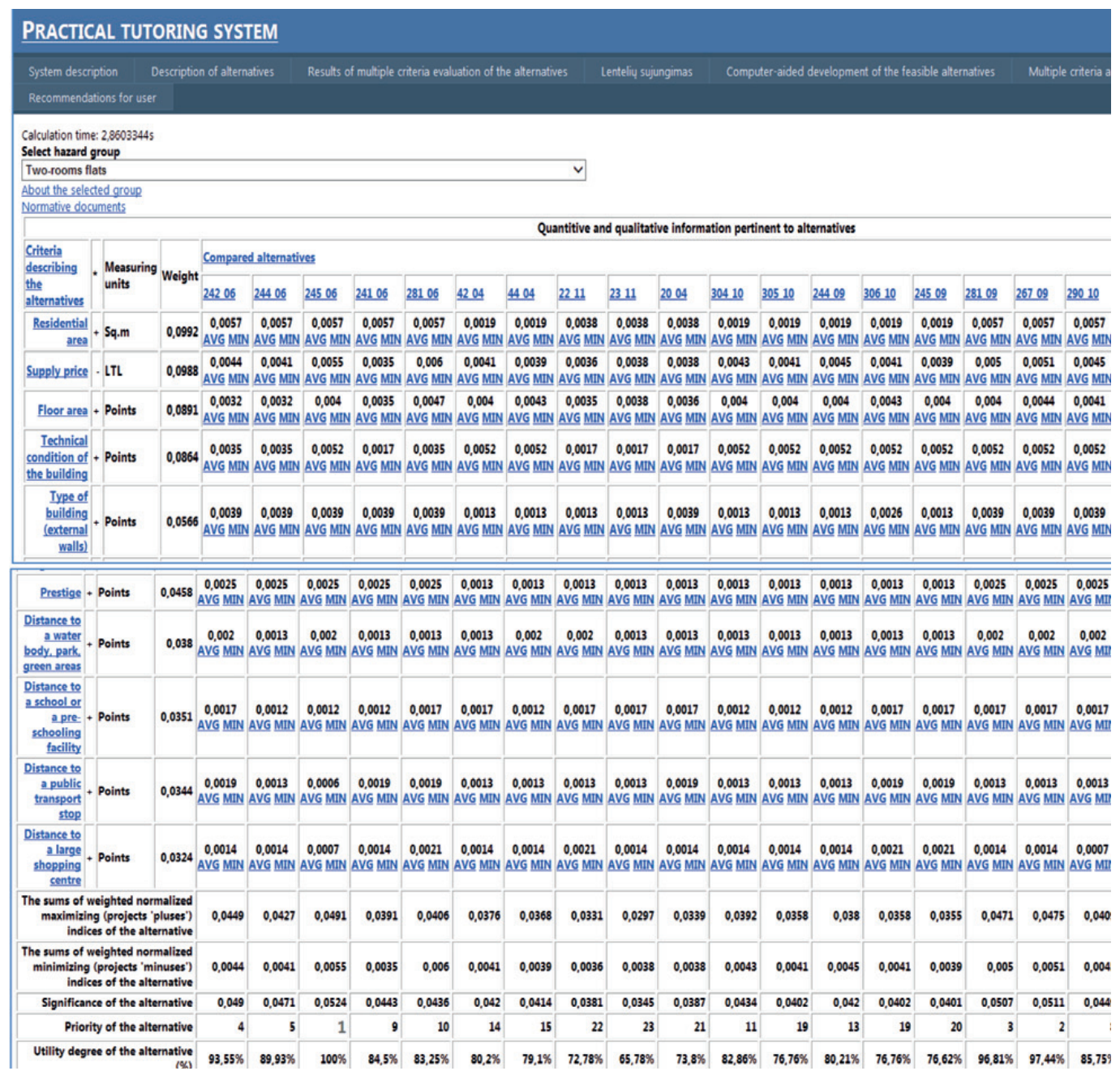

Fig. 4. Example of multiple criteria evaluation of the flats (the first lines and the last lines of the matrix with the results)

\section{Stall and jolt tactics}

Hello,

Thank you for providing me with enough time to give a thorough thought to your proposal. Considering the current market situation I believe the price I offered you earlier for the piece of property was too high. So now I'd buy your flat if you could drop the ask price by $2 \%$. I believe it would be a just price.

I'll be waiting for your reply until...

Sincerely yours,

Buyer 


\section{Go away tactics}

Hello,

I like your flat. I think I've already offered a price that corresponds to its market price.

But I do like your flat, so this time I offer 1\% (or LTL ....) on top of my previous offer.

This is my last proposal. If you fail to notify me that you agree to sell me the flat for my new price (LTL ....) within two days, my offer will expire. Then I'll probably buy another flat similar to yours, which, I believe, is a better choice to invest the amount I'm offering you today.

Sincerely yours,

Buyer

\section{TESTING THE REAL-TIME HOUSING MULTIPLE-CRITERIA BARGAINING DECISION SUPPORT SYSTEM}

To test the RTMC-BDS system, 101 flat sellers were emailed system-generated bargaining messages with the "Attractive alternative" tactics.

a)

\begin{tabular}{|c|c|c|c|c|c|c|c|c|c|c|}
\hline \multirow{2}{*}{\multicolumn{11}{|c|}{$\begin{array}{l}\text { Negotiation tactics } \\
\text { About the selected groug } \\
\text { Normative documents } \\
\end{array}$}} \\
\hline & & & & & & & & & & \\
\hline \multicolumn{11}{|c|}{ Quantitive and qualitative information pertinent to alternatives } \\
\hline \multirow[b]{2}{*}{ Criteria describing the alternatives } & \multirow[b]{2}{*}{ - Measuring } & \multirow[b]{2}{*}{ Weight } & \multicolumn{8}{|c|}{ Compared alternatives } \\
\hline & & & $\frac{\text { Retreat }}{\text { tactics }}$ & $\begin{array}{l}\text { Tactics of an } \\
\text { attractive } \\
\text { alternative }\end{array}$ & $\begin{array}{l}\text { Tactics of sales } \\
\text { comparison }\end{array}$ & $\begin{array}{l}\text { Tactics of a } \\
\text { third party }\end{array}$ & $\begin{array}{l}\text { Tactics "That's all } \\
\text { Ican afford to } \\
\text { pay" }\end{array}$ & $\begin{array}{l}\text { Tactics "Would } \\
\text { you agree to selll it } \\
\text { for ...? }\end{array}$ & $\begin{array}{l}\text { Tactics of delay and } \\
\text { shock (attempts to } \\
\text { stun) }\end{array}$ & $\begin{array}{l}\text { Tactics of an } \\
\text { unexpected } \\
\text { auction }\end{array}$ \\
\hline The offered buying price is the last possible & + Points & 0,14 & $\begin{array}{c}0,0274 \\
\text { AVG MIN }\end{array}$ & $\begin{array}{c}0,0213 \\
\text { AVG MIN }\end{array}$ & $\begin{array}{c}0,0152 \\
\text { AVG MIN }\end{array}$ & $\begin{array}{c}0,0152 \\
\text { AVG MiN }\end{array}$ & $\begin{array}{c}0,0243 \\
\text { AVG MIN }\end{array}$ & $\begin{array}{c}0,0213 \\
\text { AVG MIN }\end{array}$ & $\begin{array}{c}0,0061 \\
\text { AVG MIN }\end{array}$ & $\begin{array}{c}0,0091 \\
\text { AVG MIN }\end{array}$ \\
\hline $\begin{array}{l}\text { Possibility for the buyer to contact the } \\
\text { seller later "out of curiosity" or "just to ask" }\end{array}$ & + Points & 0,28 & $\begin{array}{c}0,07 \\
\text { AVG MIN }\end{array}$ & $\begin{array}{c}0,0544 \\
\text { AVG MIN }\end{array}$ & $\begin{array}{c}0,0389 \\
\text { AVG MIN }\end{array}$ & $\begin{array}{c}0,0389 \\
\text { AVG MIN }\end{array}$ & $\begin{array}{c}0,0544 \\
\text { AVG MIN }\end{array}$ & $\begin{array}{c}0,0078 \\
\text { AVG MIN }\end{array}$ & $\begin{array}{c}0,0078 \\
\text { AVG MIN }\end{array}$ & $\begin{array}{c}0,0078 \\
\text { AVG MIN }\end{array}$ \\
\hline $\begin{array}{l}\text { The buyer tells the agent or the seller he has } \\
\text { seen another similar house and he finds it } \\
\text { very interesting }\end{array}$ & + Points & 0,13 & $\begin{array}{c}0,026 \\
\text { AVG MIN }\end{array}$ & $\begin{array}{c}0,0334 \\
\text { AVG MIN }\end{array}$ & $\begin{array}{c}0,026 \\
\text { AVG MIN }\end{array}$ & $\begin{array}{c}0,0223 \\
\text { AVG MIN }\end{array}$ & $\begin{array}{c}0,0037 \\
\text { AVG MIN }\end{array}$ & $\begin{array}{c}0,0111 \\
\text { AVG MIN }\end{array}$ & $\begin{array}{c}0,0037 \\
\text { AVG MIN }\end{array}$ & $\begin{array}{c}0,0037 \\
\text { AVG MIN }\end{array}$ \\
\hline $\begin{array}{r}\text { The value-to-quality ratio in the eyes of the } \\
\text { husband }\end{array}$ & + Points & 0.18 & $\begin{array}{c}0,0265 \\
\text { AVG MIN } \\
\end{array}$ & $\begin{array}{c}0,0371 \\
\text { AVG MIN }\end{array}$ & $\begin{array}{c}0,0476 \\
\text { AVG MIN }\end{array}$ & $\begin{array}{r}0,0159 \\
\text { AVG MIN } \\
\end{array}$ & $\begin{array}{r}0,0053 \\
\text { AVG MIN }\end{array}$ & $\begin{array}{c}0,0159 \\
\text { AVG MIN }\end{array}$ & $\begin{array}{c}0,0265 \\
\text { AVG MIN }\end{array}$ & $\begin{array}{c}0,0053 \\
\text { AVG MIN } \\
\end{array}$ \\
\hline $\begin{array}{r}\text { The value-to-quality ratio in the eyes of the } \\
\text { wife }\end{array}$ & + Points & 0,17 & $\begin{array}{c}0,0277 \\
\text { AVG MIN }\end{array}$ & $\begin{array}{c}0,0316 \\
\text { AVG MIN }\end{array}$ & $\begin{array}{c}0,0277 \\
\text { AVG MIN }\end{array}$ & $\begin{array}{c}0,0356 \\
\text { AVG MIN }\end{array}$ & $\begin{array}{c}0,0119 \\
\text { AVG MIN }\end{array}$ & $\begin{array}{c}0,0119 \\
\text { AVG MIN }\end{array}$ & $\begin{array}{c}0,0198 \\
\text { AVG MIN }\end{array}$ & $\begin{array}{c}0,004 \\
\text { AVG MIN }\end{array}$ \\
\hline The buyer has nowhere to take more money & + Points & 0,23 & $\begin{array}{c}0,04 \\
\text { AVG MIN } \\
\end{array}$ & $\begin{array}{c}0,035 \\
\text { AVG MIN } \\
\end{array}$ & $\begin{array}{c}0,035 \\
\text { AVG MIN }\end{array}$ & $\begin{array}{c}0,005 \\
\text { AVG MIN } \\
\end{array}$ & $\begin{array}{r}0,045 \\
\text { AVG MIN } \\
\end{array}$ & $\begin{array}{r}0,04 \\
\text { AVG MIN } \\
\end{array}$ & $\begin{array}{c}0,025 \\
\text { AVG MIN }\end{array}$ & $\begin{array}{r}0,005 \\
\text { AVG MIN } \\
\end{array}$ \\
\hline
\end{tabular}

b)

\begin{tabular}{|c|c|c|c|c|c|c|c|c|}
\hline $\begin{array}{r}\text { The sums of weighted normalized maximizing (projects } \\
\text { 'pluses') indices of the alternative }\end{array}$ & 0,4178 & 0,395 & 0,3551 & 0,3087 & 0,2436 & 0,3121 & 0,2628 & 0,1354 \\
\hline $\begin{array}{l}\text { The sums of weighted normalized minimizing (projects } \\
\text { 'minuses') indices of the alternative }\end{array}$ & 0,8313 & 0,4863 & 0,5959 & 0,7768 & 0,6269 & 0,4049 & 1,0788 & 0,7095 \\
\hline Significance of the alternative & 0,9428 & 1,2925 & 1,0875 & 0,8705 & 0,9398 & 1,39 & 0,6674 & 0,7505 \\
\hline Priority of the alternative & 4 & 2 & 3 & 6 & 5 & 1 & 8 & 7 \\
\hline Utility degree of the alternative (\%) & $67,83 \%$ & $92,98 \%$ & $78,24 \%$ & $62,63 \%$ & $67,61 \%$ & $100 \%$ & $48,01 \%$ & $54 \%$ \\
\hline
\end{tabular}

Fig. 5. Fragments of multiple criteria analysis of the feasible alternatives (negotiation tactics): a - the first lines of the matrix with the results and $b$ - the last lines of the matrix with the results)

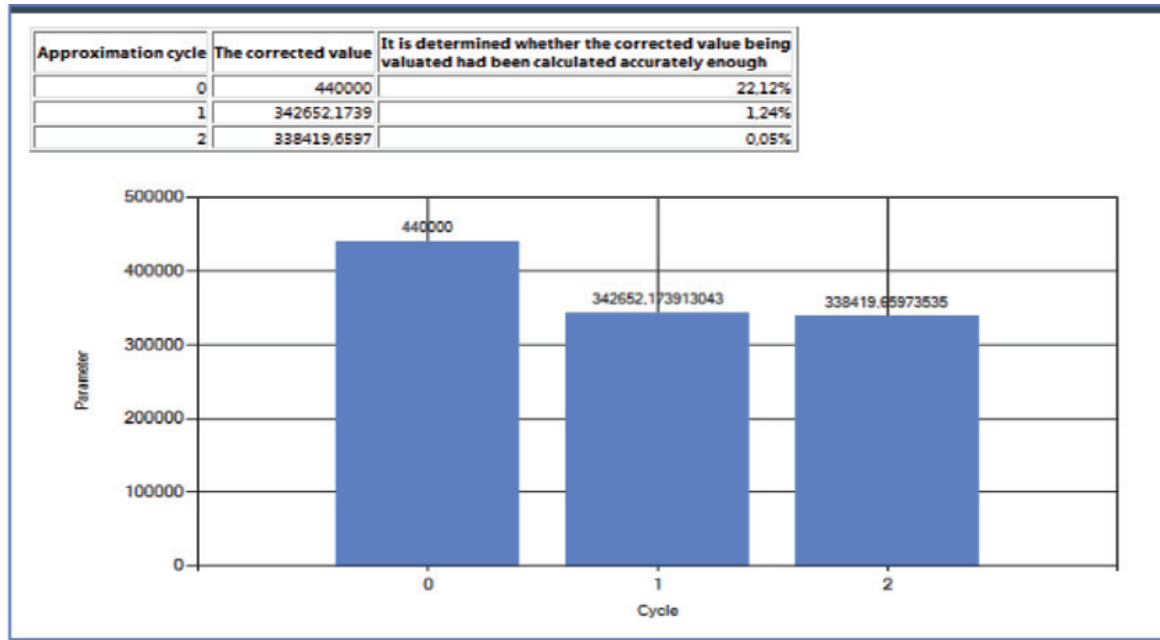

Fig. 6. Calculating the market value of a flat for sale 
The sellers' replies revealed that $63 \%$ of them were willing to bargain and agreed to cut their asking price. An analysis of their replies and a comparison of the asking price with the market value of their flats show that the more the flat's asking price exceeds the market value, the bigger the share of property sellers willing to bargain (Fig. 8).

The RTMC-BDS system was introduced to 40 potential customers of real estate agencies who accepted the invitation to take part in the study as property sellers and buyers. Once the system was tested and the simulated bargaining concluded, those who participated in the bargaining were handed out a questionnaire to answer some questions.

The results of the survey of those who took part in the system testing are outlined below. The respondents believe that:

1. The system facilitates home searching and helps the user find a suitable home faster (73\% of the respondents).

2 . The system provides comprehensive information about a home necessary for bargaining (91\%).

3. The system performs complex calculations necessary for efficient bargaining (86\%).

4. The system aids an uninformed buyer to apply housing negotiation tactics with systemgenerated bargaining emails and to bargain a lower price $(86 \%)$.

5. The system aids an inexperienced buyer to conceal from the seller his or her emotions towards the home considered for buying and hence to achieve success with negotiation tactics and to bargain a lower price (68\%).

6 . The system aids a buyer unskilled in bargaining to escape face-to-face bargaining (or make it shorter), as system-generated bargaining emails are used for bargaining (86\%).

7. A drawback of the system is that, as property markets are volatile, flats people seek to buy have changing utility criteria with changing weights $(82 \%)$.

Case of bargaining using the RTMC-BDSS:

Buyer wants to buy a two room flat in Vilnius for his parents. Currently, the parents live in another town. The buyer is already tired of the prolonged search for a suitable housing; however, he got familiar with the situation in RE market within this period. The buyer is emotionally attached to Antakalnis because it is prestigious district and here is his workplace. In Antakalnis apartments are more expensive and the supply is lower com- pared to the amount of available options in new residential developments of the city of Vilnius.

The table of initial data for bargaining was prepared by the Real-Time Housing Multiple-Criteria Bargaining Decision Support System (RTMCBDSS). Following on the developed final comparative table the multiple criteria analysis and selection of the best housing negotiation tactic are being carried out using RTMC-BDSS (see Fig. 8). In this case, the RTMC-BDSS shows that the tactics "Would you sell for .....LTL?" has the priority and the buyer might use it in order to bargain a better price for flats with IDs 267 and 245 . The second tactics recommended by the system is "An attractive alternative" tactics. The RTMC-BDSS considers each negotiation tactics and flat for sale, generates relevant bargaining e-mails and, once the buyer has reviewed and revised them, sends them to home sellers for bargaining.

Using the system, the buyer first applied the "Would you sell for .....LTL?" tactics (the first one recommended by the system), then, successfully, the tactic "An attractive alternative" (the second one recommended by the RTMC-BDSS) and bargained off a total of 5\% (or over LTL 20,000) off the initially specified flat price.

\section{CONCLUSIONS}

Based on the analysis of electronic negotiation decision support systems, considering the peculiarities of the housing market, housing searching, buying and bargaining process, also in order to bargain terms of home sale purchase agreement efficiently, the Real-Time Housing Multiple-Criteria Bargaining Decision Support System was developed.

The developed Real-Time Housing MultipleCriteria Bargaining Decision Support System facilitates housing buying and bargaining process online through the following functions: search for housing alternatives, formulation of the initial comparative table of alternatives, multiple criteria analysis of housing alternatives (to determine the priority, the utility degree), multiple criteria analysis of negotiation tactics, determination of the most useful home option for buying, real time determination of the market value of the housing alternatives and automated presentation of recommendations.

The respondents who took part in the system testing note that the system can speed up bargaining and make it more efficient because the system facilitates home searching and helps the user find a suitable home faster, while all home's advantag- 


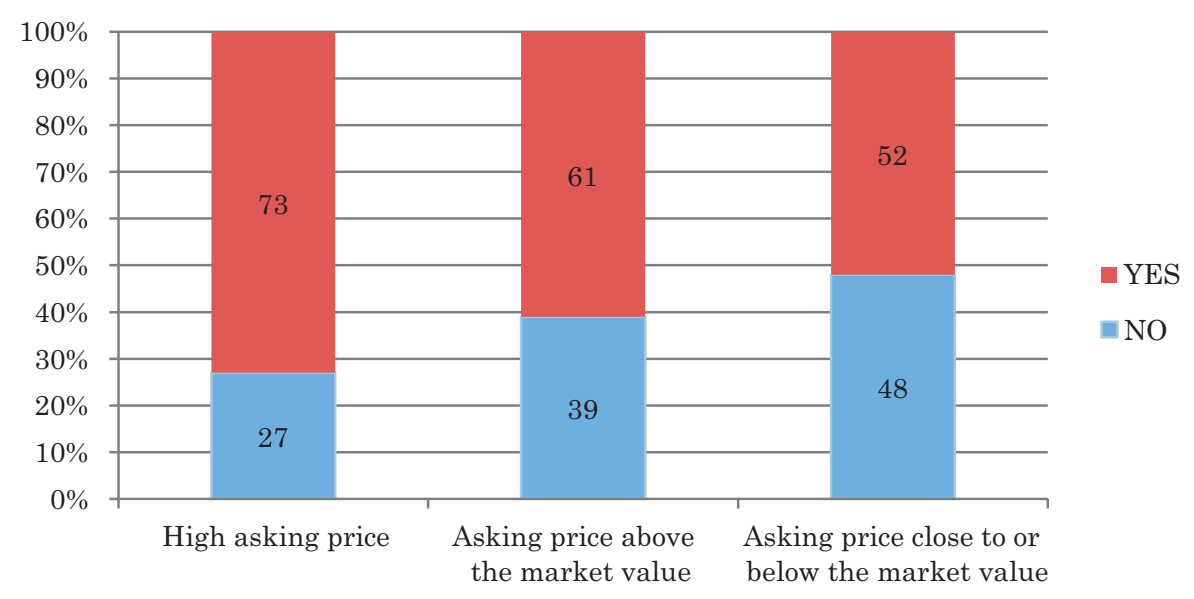

Fig. 7. The proportion of home sellers willing and not willing to bargain by their asking price compared to the market value

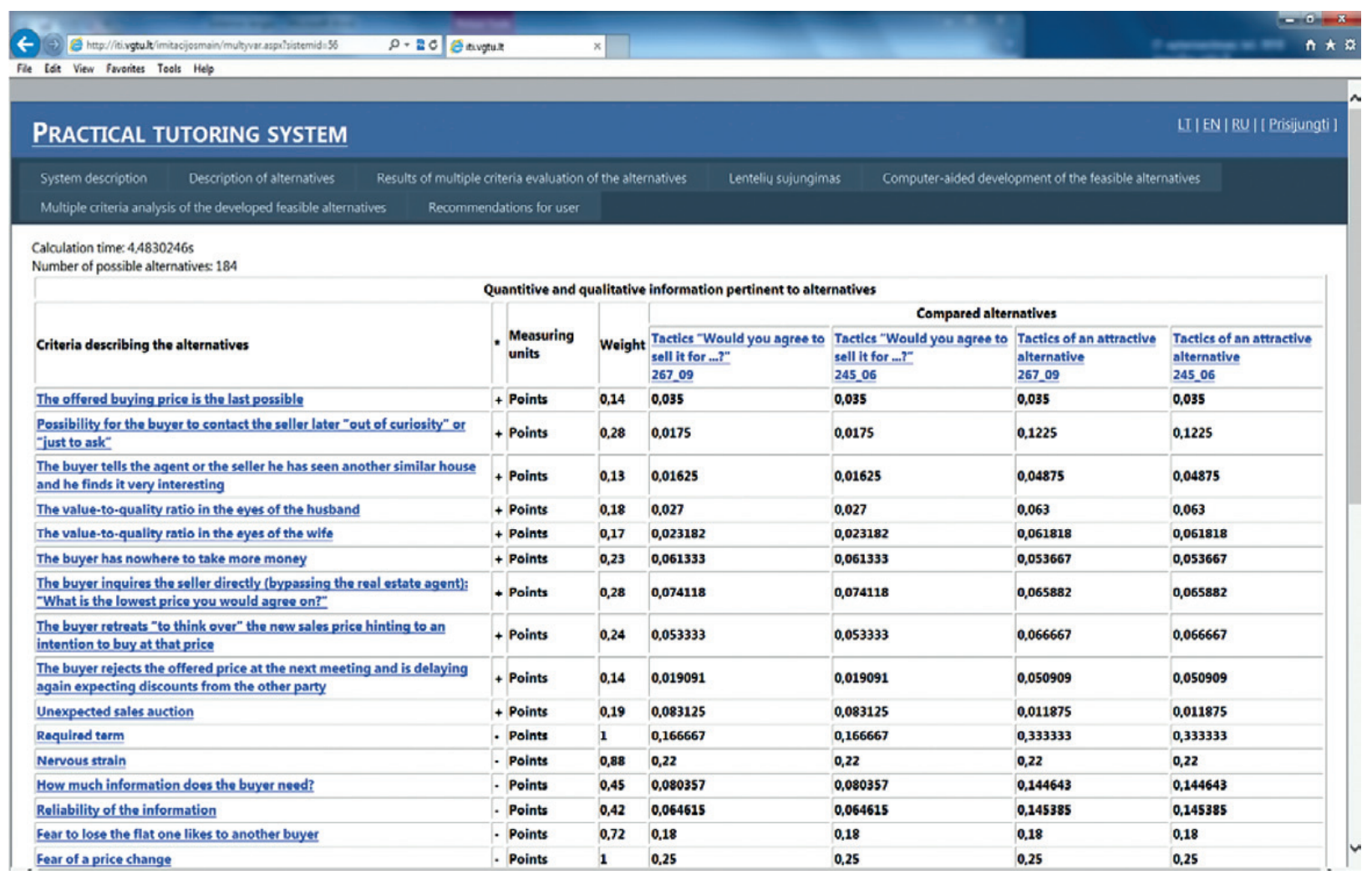

Fig. 8. Fragments of multiple criteria analysis of the feasible alternatives

es and disadvantages are considered from quantitative and qualitative perspectives. The system also provides comprehensive information about a home necessary for bargaining and performs complex calculations. Home buyers can base their bargaining decisions on comprehensive information. Unlike other negotiation systems, this system makes its users aware of the actual market value. The system aids an uninformed buyer to apply housing negotiation tactics, to escape faceto-face bargaining (or make it shorter) with system-generated bargaining emails, and to bargain a lower price. A drawback of the system is that, as property markets are volatile, flats people seek to buy have changing utility criteria with changing weights, but this limitation is easy to eliminate by resurveying experts and, based on the survey results, selecting and adding new criteria and their weights to the system.

The system's novelty and superiority to the traditional valuation and bargaining methods usually applied by market participants is the fact that it allows to cover and analyse a rather broader set of criteria and to make an integrated assessment 
of quantitative and qualitative criteria that define properties in question. The valuation process not only draws conclusions on the value, determines the priority and sets the utility degree, but also offers comprehensive interim results, such as recommendations on the impact of individual environmental factors on the value, and ways to mitigate adverse effects of the environmental factors and to achieve a better result. The market value determined by the DSS builds upon a comprehensive analysis of the environment based on expert investigations, rather than on a valuator's subjective assumptions alone.

The system may assist teaching to illustrate the nature of value formation, to determine the impact of environmental factors on value, to analyse the reasons of changing value and so on.

\section{REFERENCES}

Agrawal, M. K.; Chari, K. 2009. Learning negotiation support systems in competitive negotiations: a study of negotiation behaviors and system impacts, International Journal of Intelligent Information Technologies 5(1): 1-23.

van der Amselvoort, M.; Gettinger, J.; Koeszegi, S.; Schoop, M.; van der Wijst, P. 2011. Communication in electronic negotiations, in Dargam, F.; Delibasic, B.; Hernández, J. E.; Liu, S.; Ribeiro, R.; Zaraté, P. (Eds.). Proceeding of the EURO Working Group on Decision Support Systems (EWG-DSS), London, UK, 19-20.

Barry, B.; Friedman, R. A. 1998. Bargainer characteristics in distributive and integrative negotiation, Journal of Personality and Social Psychology 74(2): 345-359.

Bazerman, M. H.; Curhan, J. R.; More, D. A.; Valley, K. J. 2000. Negotiation, Annual Review of Psychology 51: 279-314. http://dx.doi.org/10.1146/annurev.psych.51.1.279

Carbonneau, R. A.; Vahidov, R. M. 2014. A utility concession curve data fitting model for quantitative analysis of negotiation styles, Expert Systems with Applications 41(9): 4035-4042. http://dx.doi. org/10.1016/j.eswa.2013.12.029

Cheung, S. C.; Hung, P. C. K.; Chiu, D. K. W. 2003. On the e-Negotiation of unmatched logrolling views, in Proceedings of the 36th Hawaii International Conference on System Sciences (HICSS-36), 6-9 January, 2003, Big Island, Hawaii. 10 p. http://dx.doi. org/10.1109/HICSS.2003.1173687

Chiu, D. K. W.; Cheung, S. C; Hung, P. C.; Chiu, S. Y.; Chung, A. K. 2005. Developing e-negotiation support with a meta-modeling approach in a web services environment, Decision Support Systems 40: 51-69. http://dx.doi.org/10.1016/j.dss.2004.04.004

Cummins, J. E. 1999. Not One dollar more! New York. $286 \mathrm{p}$.

Diekmann, K. A.; Tenbrunsel, A. E.; Shah, P. P.; Schroth, H. A.; Bazerman, M. H. 1996. The descrip- tive and prescriptive use of previous purchase price in negotiations, Organizational Behavior and Human Decision Processes 66(2): 179-191. http://dx.doi. org/10.1006/obhd.1996.0047

Druckman, D.; Filzmoser, M.; Gettinger, J. H.; Koeszegi, S. T.; Vetschera, R. 2012. 2.0 2 G eNerationS avenues for the next generation of pro-active negotiation support, in Proceedings of the International Conference on Group Decision and Negotiation, 2024 May, 2012, Recife, Brazil. 46 p.

Flavián-Blanco, C.; Gurrea-Sarasa, R.; Orús-Sanclemente, C. 2011. Analyzing the emotional outcomes of the online search behavior with search engines, Computers in Human Behavior 27(1): 540-551. http://dx.doi.org/10.1016/j.chb.2010.10.002

Galin, A.; Gross, M.; Gosalker, G. 2007. E-negotiation versus face-to-face negotiation what has changed if anything?, Computers in Human Behavior 23(1): 787-797. http://dx.doi.org/10.1016/j.chb.2004.11.009

Garg, N.; Wansink, B.; Inman, J. J. 2007. The influence of incidental affect on consumers' food intake, Journal of Marketing 71(1): 194-206. http://dx.doi. org/10.1509/jmkg.71.1.194

Geiger, I.; Parlamis, J. 2014. Is there more to email negotiation than email? The role of email affinity, Computers in Human Behavior 32: 67-78. http://dx.doi. org/10.2139/ssrn.1866506

Gettinger, J.; Dannenmann, A.; Druckman, D.; Filzmoser, M.; Mitterhofer, M.; Reiser, A.; Schoop, M.; Vetschera, R.; van der Wijst, P.; Koszegi, S. 2012. Impact of and interaction between behavioral and economic decision support in electronic negotiations, Lecture Notes in Business Information Processing 121: 151-165. http://dx.doi.org/10.1007/978-3-64232191-7_11

Gibler, K. M.; Nelson, L. S. 2003. Consumer behavior applications to real estate education, Journal of Real Estate Practice and Education 6(1): 63-83. http:// dx.doi.org/10.1.1.198.6732\&rep=rep1\&type=pdf

Gruneberg, S.; Ive, G. J. 2000. The economics of the modern construction sector. Basingtoke: Palgrave Macmillan. 304 p. http://dx.doi.org/10.1057/9780230510432

Kemp, E.; Bui, M.; Chapa, S. 2012. The role of advertising in consumer emotion management, International Journal of Advertising 31(2): 339-353. http://dx.doi. org/10.2501/IJA-31-2-339-353

Kersten, G.; Lai, H. 2010. Electronic negotiations: foundations, systems and processes, in Kilgour, D. M.; Eden, C. (Eds.). Handbook of group decision and negotiation. Dordrecht: Springer Science + Business Media B.V., 361-392. http://dx.doi.org/10.1007/97890-481-9097-3_22

Kim, J. B.; Kersten, G. E.; Law, K. P.; Strecker, S. 2007. E-negotiation system development: using negotiation protocols to manage software components, Group Decision and Negotiation 16: 321-334. http://dx.doi. org/10.1007/s10726-006-9052-8

Kummerow, M.; Lun, J. C. 2005. Information and communication technology in the real estate industry: productivity, industry structure and market efficiency, Telecommunications Policy 29(2/3): 173-191 http://dx.doi.org/10.1016/j.telpol.2004.12.003 
Li, H. 1996. Case-based reasoning for intelligent support of construction negotiation, Information and Management 30: 231-238. http://dx.doi.org/10.1016/ S0378-7206(96)01058-0

McLean, A.; Eldred, G. W. 2005. Investing in real estate. $5^{\text {th }}$ ed. John Wiley and Sons. 309 p.

McKenzie, D. J.; Betts, R. M. 2006. Essentials of real estate economic. $5^{\text {th }}$ ed. Thompson South-Western. $462 \mathrm{p}$.

NAR. 2012. The digital house hunt: consumer and market trends in real estate [online]. The National Association of Realtors (NAR). Available at: http://www. realtor.org/reports/digital-house-hunt [accessed 10 September 2013]

NAR. 2013. Highlights from the 2013 profile of home buyers and sellers [online]. The National Association of Realtors (NAR). Available at: http://www.realtor. org/reports/highlights-from-the-2013-profile-of-homebuyers-and-sellers [accessed 1 April 2014]

Paliwal, A.; Nabil, A.; Vijayalakshmi, A.; Yesha, Y. 2003. Electronic negotiation of government contracts through transducers, in ACM International Conference Proceeding Series. Vol. 130 Proceedings of the 2003 annual national conference on Digital government research, Boston, MA, 1-6.

Pommeranz, A.; Wiggers, P.; Brinkman, W. P.; Catholijn, M.; Jonker, C. M. 2012. Social acceptance of negotiation support systems: scenario-based exploration with focus groups and online survey, Cognition, Technology \& Work 14(4): 299-317. http://dx.doi. org/10.1007/s10111-011-0181-8

Rangaswamy, A.; Shell, G. R. 1997. Using computers to realize joint gains in negotiations: toward an "Electronic bargaining table", Management Science 43(8): 1147-1163. http://dx.doi.org/10.1287/mnsc.43.8.1147

Raiffa, H. 1982. The art and science of negotiation. Cambridge, MA: Harvard University Press. 373 p.

RENI. 2014. Mastering email negotiations in real estate [online]. Real Estate Negotiation Institute (RENI). Available at: http://negotiationexpertise.com/ courses/e-negotiations [accessed 1 April 2014]

Schoop, M. 2004. The worlds of negotiation, in Proceedings of the 9th International Working Conference on the Language-Action Perspective on Communication Modelling (LAP 2004), June, 2004, New Brunswick, USA, 179-196.

Schoop, M.; Jertila, A.; List, T. 2003. Negoisst - a negotiation support system for business-to-business electronic commerce, Data Knowledge and Engineering 47(3): 371-401. http://dx.doi.org/10.1016/S0169. 023X(03)00065-X
Šliogerienè, J.; Kaklauskas, A.; Štreimikienè, D.; Bianchi, M. 2012. Multiple criteria decision support system for the assessment of energy generation technologies considering the dimension of values, International Journal of Strategic Property Management 16(4): 370-391. http://dx.doi.org/10.3846/16487 15X.2012.722132

The Nobel Foundation. 2002. Foundations of behavioral and experimental economics: Daniel Kahneman and Vernon Smith [online]. The Sveriges Riksbank Prize in Economic Sciences in Memory of Alfred Nobel 2002. Available at: http://nobelprize.org/nobel_prizes/ economics/laureates/2002/ecoadv02.pdf [accessed 25 September 2008]

Urbanavičienè, V.; Kaklauskas, A.; Zavadskas, E. K. 2009. The conceptual model of construction and real estate negotiation, International Journal of Strategic Property Management 13(1): 53-70. http://dx.doi. org/10.3846/1648-715X.2009.13.53-70

Valley, K.; Thomson, L.; Gibbons, R.; Bazerman, M. H. 2002. How communication improves efficiency in bargaining games, Journal of Games and Economic Behavior 36: 127-155. http://dx.doi.org/10.1006/ game.2001.0855

Vetschera, R. 2007. Preference structures and negotiator behavior in electronic negotiations, Decision Support Systems 44(1): 135-146. http://dx.doi.org/10.1016/j. dss.2007.03.007

Yavas, A. 2007. Introduction: real estate brokerage, Journal of Real Estate Finance and Economics 35: 1-5. http://dx.doi.org/10.1007/s11146-007-9030-1

Yen, J.; Hu, J.; Bui, T. X. 2000. Intelligent clearinghouse: electronic marketplace with computer-mediated negotiation supports, in Proceedings of the 33rd Hawaii International Conference on System Sciences, January, 2000. 1048 p. http://dx.doi.org/10.1109/HICSS.2000.926633

Yuan, Y.; Head, M.; Du, M. 2003. The effects of multimedia communication on web-based negotiation, Group Decision and Negotiation 12(2): 89-109. http://dx.doi. org/89-109.10.1023/A:1023016804379

Zavadskas, E. K.; Kaklauskas, A. 1996a. The new method of multicriteria evaluation of projects, in DeutschLitauisch-Polnisches Kolloquium zum Baubetriebswesen. Hochschule für Technik, Wirtschaft und Kultur in Leipzig. 3 Jahrgang. Sonderheft 1(96): 3-8.

Zavadskas, E. K.; Kaklauskas, A. 1996b. Determination of an efficient contractor by using the new method of multicriteria assessment, in Langford, D. A.; Retik, A. (Eds.). International symposium for the organisation and management of construction. Shaping theory and practice, vol. 2: Managing the construction project and managing risk. CIB W 65. E and FN SPON, London, 94-104. 